\title{
Aza- and Azo-Stilbenes: Bio-Isosteric Analogs of Resveratrol
}

\author{
Gérard Lizard ${ }^{1}$, Norbert Latruffe ${ }^{1}\left(\mathbb{1}\right.$ and Dominique Vervandier-Fasseur ${ }^{2, *}$ (D) \\ 1 Team Bio-PeroxIL, Biochemistry of the Peroxisome, Inflammation and Lipid Metabolism (EA7270), \\ University of Bourgogne Franche-Comté, Inserm, 21000 Dijon, France; gerard.lizard@u-bourgogne.fr (G.L.); \\ norbert.latruffe@u-bourgogne.fr (N.L.) \\ 2 Team OCS, Institute of Molecular Chemistry of University of Burgundy (ICMUB UMR CNRS 6302), \\ University of Bourgogne Franche-Comté, 21000 Dijon, France \\ * Correspondence: dominique.vervandier-fasseur@u-bourgogne.fr; Tel.: +33-3-8039-9036
}

Academic Editor: Corrado Tringali

Received: 19 December 2019; Accepted: 23 January 2020; Published: 30 January 2020

\begin{abstract}
Several series of natural polyphenols are described for their biological and therapeutic potential. Natural stilbenoid polyphenols, such as trans-resveratrol, pterostilbene and piceatannol are well-known for their numerous biological activities. However, their moderate bio-availabilities, especially for trans-resveratrol, prompted numerous research groups to investigate innovative and relevant synthetic resveratrol derivatives. This review is focused on isosteric resveratrol analogs aza-stilbenes and azo-stilbenes in which the $\mathrm{C}=\mathrm{C}$ bond between both aromatic rings was replaced with $\mathrm{C}=\mathrm{N}$ or $\mathrm{N}=\mathrm{N}$ bonds, respectively. In each series, synthetic ways will be displayed, and structural sights will be highlighted and compared with those of resveratrol. The biological activities of some of these molecules will be presented as well as their potential therapeutic applications. In some cases, structure-activity relationships will be discussed.
\end{abstract}

Keywords: trans-resveratrol; aza-stilbene; azo-stilbene; bio-isosterism; structure-activity relationship

\section{Introduction}

Among natural polyphenolic compounds, polyphenolic stilbenoids hold an important place. They are widespread in a large number of plants. The leader of this series is a phytoalexin, trans-resveratrol (RSV) or 3,4',5-trihydroxystilbene (1) (Figure 1) discovered in 1940 in Japan by M. Takaoka from Veratrum grandiflorum where its name comes from: VERATRum/resVERATRol [1].

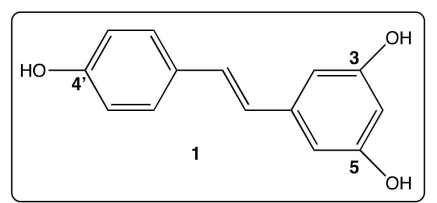

Figure 1. Structure of trans-Resveratrol (1).

This natural polyphenol is found in numerous species, for instance, in roots of Asiatic plant Polygonum cuspidatum [2], in several edible plants [3] especially in fruit including grapes where RSV is in the form of phytoalexin [4,5], and subsequently in red wine [6]. RSV is widely studied since the 90s. Because of its numerous biological activities, such as anti-oxidant [7], antitumoral [8], antiviral [9], and anti-inflammatory activities [10] and more recently due to its differentiating properties [11,12]. In addition, trans-resveratrol is a neuroprotective agent [13], and acts against platelet aggregation [14]. RSV is a sirtuin-activating compound (STAC) which may increase lifespan in metazoans (Caenorhabditis elegans, Drosophila melanogaster, mice) by a mechanism related with a caloric restriction [15-17]. 
Subsequently, this polyphenol is effective in treating metabolic disorders [18]. It is now recognized that a diet rich in these health-beneficial molecules allows a good level of health to be maintained [19].

However, despite its therapeutic potential, so far RSV could not be used as such in clinical trials because its quick metabolism and its weak bio-availability due to its low water solubility [20,21]. In order to enhance the bio-availability of RSV and subsequently, its therapeutic potency while keeping the hydroxylated stilbene scaffold, numerous research groups have synthesized an infinite number of RSV analogs and evaluated them for various biological activities. Several ways to modify RSV may be considered, for instance, transformation of phenolic functions in ester or ether functions [22-24], substitution with various groups on the phenyl rings [25-28] or by replacing a phenyl ring with an aromatic heterocycle [29,30] or with an organometallic cycle [27]. The concept of bio-isosterism may be applied in the case of RSV analogs [31]. Indeed, the $\mathrm{C}=\mathrm{C}$ bond may be seen as a bridge between both phenyl rings, allowing an electronic delocalization on the whole molecule. This electronic feature plays a primordial role especially in anti-oxidant activity of the polyphenolic molecule. Thus, some RSV analogs have been designed by replacing the $C=C$ bond with isosteric $C=N$ or $N=N$ bonds or with an aromatic ring [32-35]. Another way to overcome the problems related to the low water solubility of RSV is to load it into nanoparticles or liposomes [36-39]. Several reviews have focused on several series of RSV analogs especially natural RSV analogs [24], RSV analogs displaying pharmacological activities [40,41], multi-targeted drug RSV analogs [42] and RSV analogs with various substituents on both phenyl rings [28].

The aim of this review is to specifically focus on both aza-stilbenes (AZA-ST) and azo-stilbenes (AZO-ST) whose $\mathrm{C}=\mathrm{C}$ bond is replaced by a $\mathrm{C}=\mathrm{N}$ bond or $\mathrm{N}=\mathrm{N}$ bond, respectively (Figure 2). Each series will be examined with respect to synthetic ways as well as structural sights and biological activities. In some cases, a relationship between the latter will be highlighted.

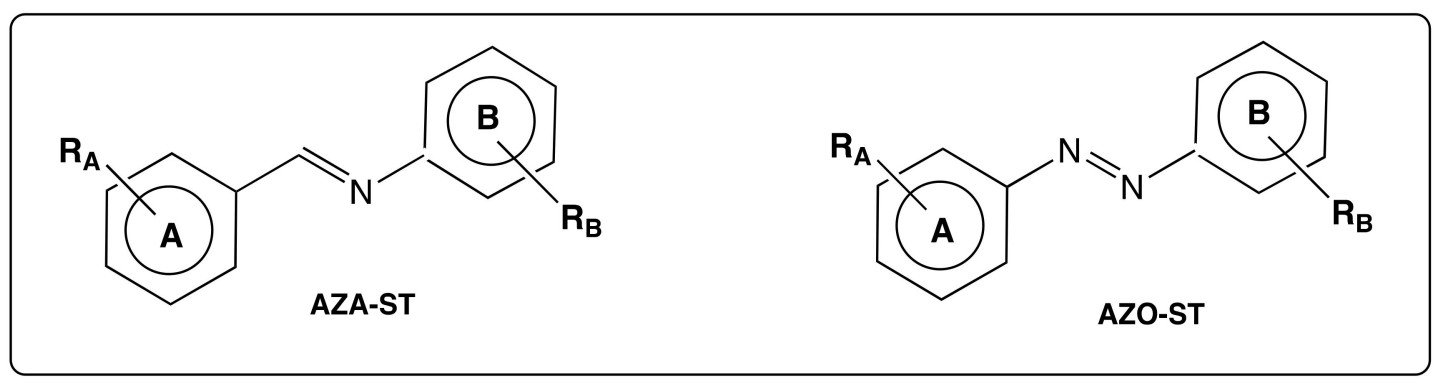

Figure 2. Structure of aza-stilbenes (AZA-ST) and azo-stilbenes (AZO-ST).

\section{Structural and Synthetic Sights of AZA-ST and AZO-ST Compared with trans-RSV}

\subsection{Isosteric Features of $C=N$ and $N=N$ Bonds}

Numerous RSV derivatives have been designed by keeping the original stilbenoid skeleton and changing the nature and/or the number of substituents on aromatic rings in order to enhance the bio-availability of the molecule, to better target the receptors, or to carry pharmacophore in the case of multi-targeted ligand derivatives [28]. These modifications usually require multi-steps syntheses which are often easy to carry out. The bio-isosterism concept is a discerning tool in drug design and may be used in the case of RSV analogs. According to Grimm's hydride displacement law [31], nitrogen atom and $\mathrm{CH}$ group having the same number of valence electrons are isosters. Thus, the replacement of one or both $\mathrm{CH}$ in the double bond of stilbene by one or two nitrogen atoms is an easy synthetic way to obtain bio-isosters of RSV. In such isosters, the number of valence electrons does not change with respect to the parent molecule electronic environment of the stilbene scaffold and subsequently, the resulting RSV analogs may have biological activities similar to, or even superior to RSV. 


\subsection{Synthetic Pathways for Obtaining AZA-ST and AZO-ST}

Among the numerous synthetic ways to get RSV derivatives bearing a $\mathrm{C}=\mathrm{C}$ bond, the key-step is always the formation of this linkage which, can be formed by different chemical methods including Perkin [43], Wittig [25], Horner-Wittig-Emmons [44], Heck [25] and Suzuki [45] reactions from starting aromatic aldehydes or aryl bromide (Figure 3). These methods are summarized in the figure below (Figure 3); some of them require protection steps of phenolic functions.

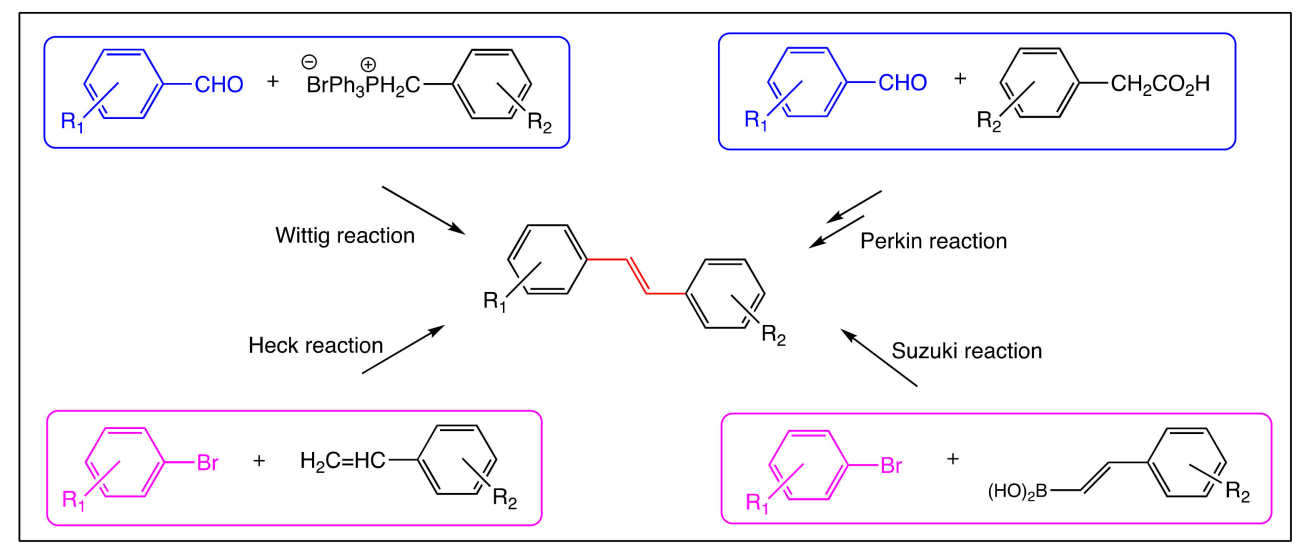

Figure 3. Principal synthetic methods for obtaining stilbene derivatives: Wittig method [25], Perkin method [43], Heck method [25] and Suzuki method [45].

Aza-stilbenes (AZA-ST) are commonly obtained by one-step reactions between aromatic aldehydes and primary aromatic amines. These one-step reactions may be carried out in refluxing ethanol [46], in refluxing toluene in a Dean-Stark apparatus [47] or in water at $25^{\circ} \mathrm{C}$ during $2 \mathrm{~h}$ [48] or 3 days [33] (Scheme 1). The reagents used to carry out these straightforward condensation reactions are mostly commercially available allowing to obtain large series of aza-stilbenes, most of them being substituted with hydroxyl groups.

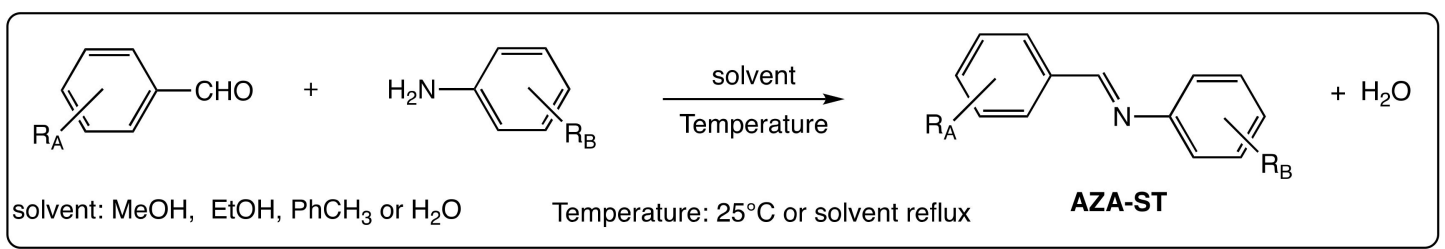

Scheme 1. Synthetic methods for obtaining aza-stilbenes (AZA-ST).

In contrast, the synthesis of azo-stilbenes (AZO-ST) requires several steps: preparation of a diazonium salt from an aromatic primary amine followed by diazo-coupling reaction between this salt and an aromatic compound [32,49] (Scheme 2). As in the case of AZA-ST, most AZO-ST are substituted with hydroxyl groups. Thus, the library of AZO-ST is large because of the commercial availability of the reagents.

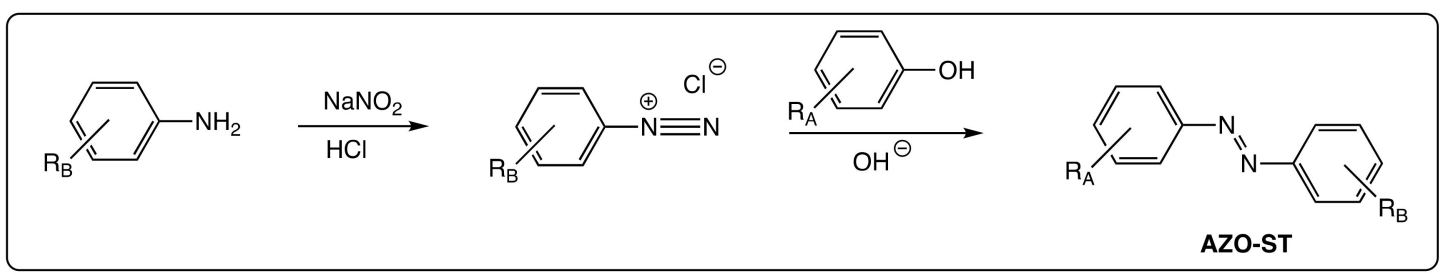

Scheme 2. Synthetic methods for obtaining Azo-stilbenes (AZO-ST). 
However, reported works about aza-stilbenes are more numerous than those concerning azo-stilbenes, probably because of their asymmetrical double bond which may afford more structural, chemical and biological specifications.

\subsection{Symmetry or Dissymmetry of Double Bonds}

The $\mathrm{N}=\mathrm{N}$ bond in AZO-ST is symmetric as in the case of RSV and does not provide an electronic influence on one or the other of the aromatic rings, especially on their substituents. In contrast, the presence of imino bond $\mathrm{C}=\mathrm{N}$ in AZA-ST induces a dissymmetry inside the stilbene core. According to the number and positions of hydroxyl groups on both aromatic rings A and B (Figure 2), their position with respect to the nitrogen atom in the linkage, mono or poly hydroxy AZA-ST may give rise to various biological studies. Indeed, the lone electronic pair of the nitrogen atom can play a role in the stabilization of a phenoxyl radical or may allow an intramolecular hydrogen bond. In addition, the imino bond is polarized and the carbon atom may be attacked by a nucleophilic agent, such as a thiol group of a cysteine residue. These features that do not appear in the case of RSV impute to aza-stilbenes specific behaviors in biological environment (Scheme 3).

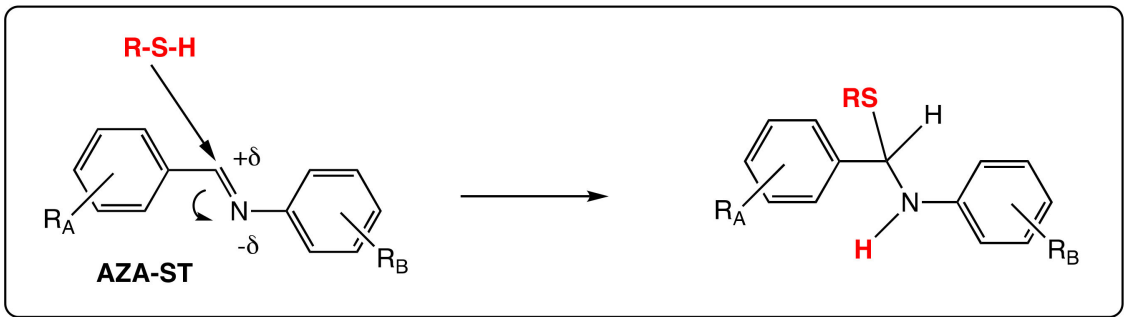

Scheme 3. Example of the nucleophilic attack of a thiol on an imino bond in AZA-ST.

\section{Biological Activities of Aza-Stilbenes}

\subsection{Aza-Stilbenes Bearing A Hydroxyl Group in Ortho Position of Cycles A or/and B}

Anti-oxidant activity is widespread in polyphenols and especially in the case of resveratrol. At first, the comparison between RSV and its imino analogs has been focused on anti-oxidant and radical scavenging activities by different research groups. The high anti-oxidant activities of AZA-ST 2 towards 2,2-diphenyl-1-picrylhydrazyl (DPPH) radical and galvinoxyl (GO) radical have been explained by the acidity of the phenolic proton due to an intramolecular hydrogen bond between this phenolic proton and the nitrogen atom in the imine group (Figure 4) [48]. In addition, the ${ }^{1} \mathrm{H}-\mathrm{NMR}$ spectrum of 2 showed high chemical shifts for such phenolic protons $(\delta=12.25$ to $14.19 \mathrm{ppm})$ that are typical of acidic protons.

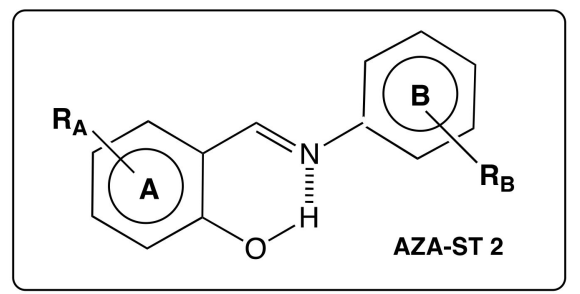

Figure 4. AZA-ST 2 bearing OH group in ortho position in ring A [48].

The authors have suggested the following mechanism in three steps [48]. The spontaneous release of the phenolic proton leading to the formation of a phenolate anion may trigger the anti-oxidant mechanism in AZA-ST $2\left(\mathrm{ArOH} \rightarrow \mathrm{ArO}^{-}+\mathrm{H}^{+}\right)$. Indeed, the phenolate anion loses an electron in favor of a free radical $\mathrm{R}^{\bullet}\left(\mathrm{ArO}^{-}+\mathrm{R}^{\bullet} \rightarrow \mathrm{ArO}^{\bullet}+\mathrm{R}^{-}\right)$especially since the phenoxyl radical is stabilized on the aromatic ring and anion $\mathrm{R}^{-}$is neutralized by proton provided in the first step $\left(\mathrm{R}^{-}+\mathrm{H}^{+} \rightarrow \mathrm{R}-\mathrm{H}\right)$. 
Radical scavenging activities (RSA) of compounds of AZA-ST series 3 (Figure 5) against DPPH radical have been studied [50,51]. Imino RSV analogs 3 bearing a hydroxyl group in ortho position of cycle B have shown a better activity than the parent molecule [51]. The lone electronic pair of nitrogen atom would overlap with the phenoxyl radical at ortho position of the cycle B, initiated by the scavenging of DPPH radical. On the other hand, the presence of a catechol group on cycle A in AZA-ST 3a increased the anti-oxidant activity because the resulting phenoxyl radical may be stabilized by resonance and formed subsequently a $o$-quinone [52]. Indeed, compound 3a was the most effective anti-oxidant agent of this series against DPPH radical and provided an $\mathrm{IC}_{50}$ value (expressed in $\mu \mathrm{M}$ ) 6-fold lower than RSV. In addition, compounds in the AZA-ST series 3 were evaluated for their ability to quench singlet oxygen ${ }^{1} \mathrm{O}_{2}$ by using EPR spin-trapping technique. All of them appeared to be better quenchers than RSV, especially compound $\mathbf{3 b}$, whose IC50 value (expressed in $\mu \mathrm{M}$ ) was 15-fold lower compared to that of the parent molecule [51]: the IC50 of compound $\mathbf{3 b}$ determined with the EPR spin-trapping technique was $(0.99 \pm 0.06) \mu \mathrm{M}$ whereas the IC50 value of RSV was $(16.94 \pm 0.73) \mu \mathrm{M}$.

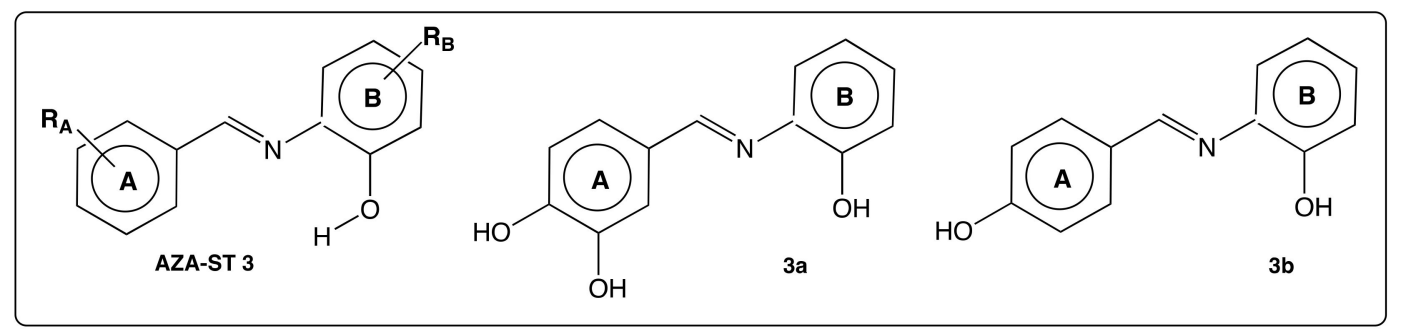

Figure 5. Structure of compounds of AZA-ST series $\mathbf{3}$ and AZA-ST $\mathbf{3 a}$ and $\mathbf{3 b}$ bearing $\mathrm{OH}$ in ortho position in ring $\mathbf{B}$ [51].

In addition to anti-oxidant features of imino RSV analogs, Zhang's group has shown a correlation between radical scavenging activities of different aza-stilbenes and their abilities to chelate transition metal ions such as $\mathrm{Cu}^{2+}$ and $\mathrm{Fe}^{3+}$, especially in the case of AZA-ST 4a (Figure 6) [53]. The authors have suggested that the "N=C=C-OH" sequence (shown in red in Figure 6) was a "metal ion-binding motif".

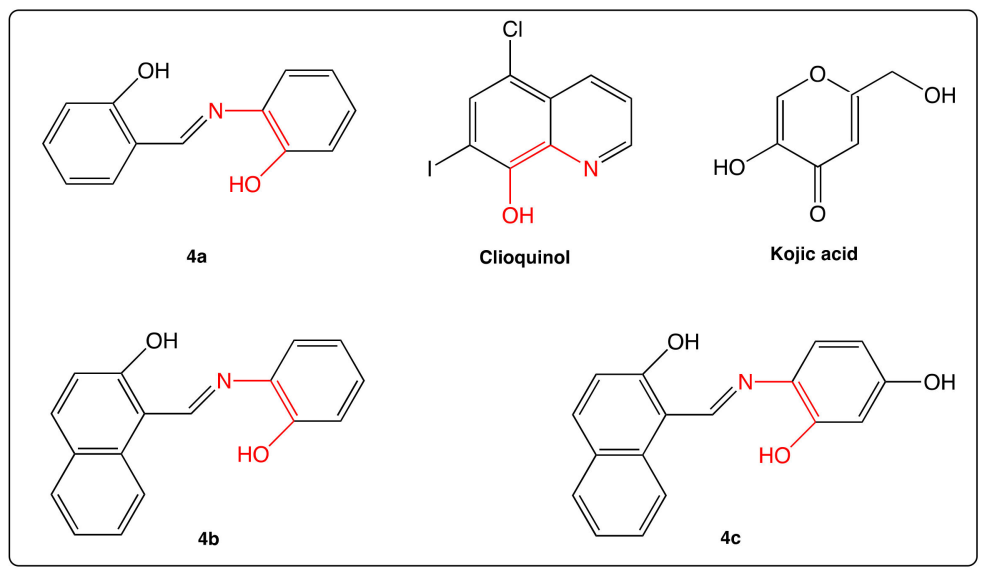

Figure 6. Structure of clioquinol, kojic acid and AZA-ST 4a-c.

Free radicals and transition metal ions including $\mathrm{Cu}^{2+}, \mathrm{Fe}^{2+}$ and $\mathrm{Fe}^{3+}$ catalyze oxidative damages as does the Fenton reaction $\left(\mathrm{Fe}^{2+}+\mathrm{H}_{2} \mathrm{O}_{2} \rightarrow \mathrm{Fe}^{3+}+\mathrm{OH}^{-}+\mathrm{HO}^{\bullet}\right)$ in some age-related diseases by initiating decomposition reactions of hydrogen peroxide $\left(\mathrm{H}_{2} \mathrm{O}_{2}\right)$ with metal ions to generate the hydroxyl radical $\left(\mathrm{HO}^{\bullet}\right)$, which is a powerful pro-oxidant. Therefore, the AZA-ST $\mathbf{4 b - c}$ (Figure 6) were designed by conjugation of RSV and clioquinol, both compounds being different agents against Alzheimer's disease. Indeed, in vitro, RSV is known for its inhibition of the aggregation of amyloid- $\beta(A \beta)[54,55]$, the main component of amyloid plaques in Alzheimer's diseases; clioquinol, bearing a metal ion-binding motif, is fit to slow down the neurological decline in early stage clinical trials [56]. To combine both features 
and strengthen the activity against Alzheimer's disease, ionophoric polyphenols $4 \mathbf{b}$ and $4 \mathbf{c}$, bearing a hydroxyl group in ortho position of both aromatic cycles, were synthesized [57]. The ortho position of hydroxyl group on ring B was essential to keep the same ability than clioquinol to chelate $\mathrm{Cu}^{2+}$ for an efficient activity. In contrast, the involvement of the lone electronic pair of nitrogen in the metal complexation prevents intramolecular hydrogen bonding with hydroxyl group in position ortho of cycle A as in the case of AZA-ST 2 [48]. However, this phenolic group is crucial for scavenging free radicals produced during the interaction between abnormal amyloid- $\beta(A \beta)$ and $\mathrm{Cu}^{2+}[58]$.

AZA-ST 4a has been evaluated for its ability to inhibit tyrosinase. Indeed, tyrosinase is a copper-containing protein; it is implied in the melanin biosynthesis in melanocytes and subsequently in hyperpigmentation of the skin. Chelators of copper ions, such as kojic acid (Figure 6) are good candidates to inhibit tyrosinase action [59]. Given its feature to bind $\mathrm{Cu}^{2+}$ ion [53], AZA-ST 4a (Figure 6) was evaluated for its ability to inhibit tyrosinase by Lima's group [60]. Compound 4a turned out to provide a lower tyrosinase inhibitory activity than kojic acid; however, compound 4a showed a better depigmenting activity than RSV.

The compounds in the compounds of the AZA-ST series 5 (Figure 7) were tested for their antioxidant activities and compared to RSV [61]. They were more effective DPPH radical scavengers than RSV. In addition, compounds $5 \mathbf{a}$ and $\mathbf{5 e}$ turned to provide anti-inflammatory properties.

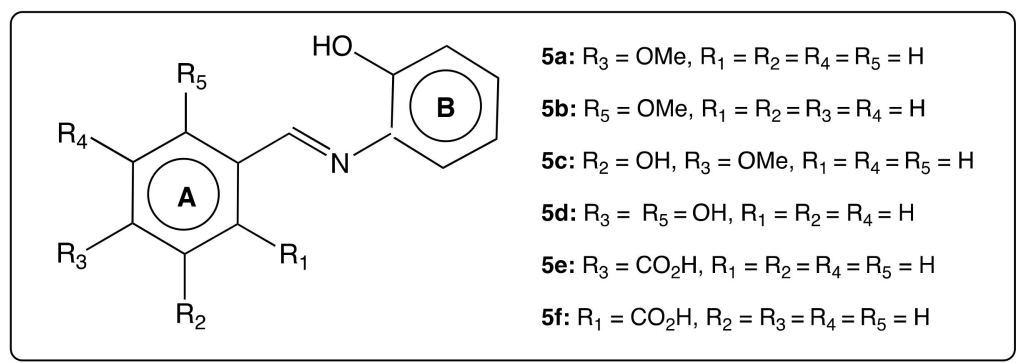

Figure 7. Structure of the compounds of the AZA-ST series 5 (AZA-ST 5) [61].

Apart from the fact that the lone pair of nitrogen atom may play crucial roles in anti-oxidant activities and metal chelation, polarization of the imino bond providing an electrophilic character to the carbon atom is essential in reactions with nucleophilic agents, such as a thiol function of the cysteine residues in proteins. Among such proteins, Keap-1 (Kelch-like ECH-associated protein 1) is a major repressor of Nrf2 (Nuclear factor erythroid-2-related factor 2), a transcription factor regulating the expression of several genes encoding for enzymes involved in the control of RedOx homeostasis. Indeed, Keap-1 may form a complex with Nrf2, that prevents the transcription factor to bind to antioxidant response elements (ARE) in the nucleus. Li's group has shown the ability of AZA-ST $3 \mathbf{a}$ and $\mathbf{6}$ (Figure 8) to activate Nrf2 and proposed the following mechanism: Keap-1 is kept close to AZA-ST 3a or $\mathbf{6}$ by interactions between the protein and hydroxyl (or methoxyl for $\mathbf{6}$ ) groups in para and meta positions of cycle A and ortho position of cycle B [33]. These interactions give a conformation to the aza-stilbene as the thiol group of cysteine residue may attack the carbon atom of the imino linkage to form a covalent bond and cause the release of Nrf2 (Figure 8) [33]. In this case, hydroxyl groups of both aromatic cycles are involved either upon interactions between the lone pairs of oxygen atoms and Keap-1 either by intramolecular hydrogen bonds with this protein.

Other compounds of a new AZA-ST series 7 (Figure 9) bearing a hydroxyl group in the ortho position of cycle $B$ were synthesized and have shown promising anti-leishmanicidal and antituberculosis activities [62]. The authors suggest that activity of compounds 7a-7f (which appear to be moderate) depends on the electronic density of the substituent in para position of cycle A. In contrast, the role of the hydroxyl group in cycle B was not mentioned. 


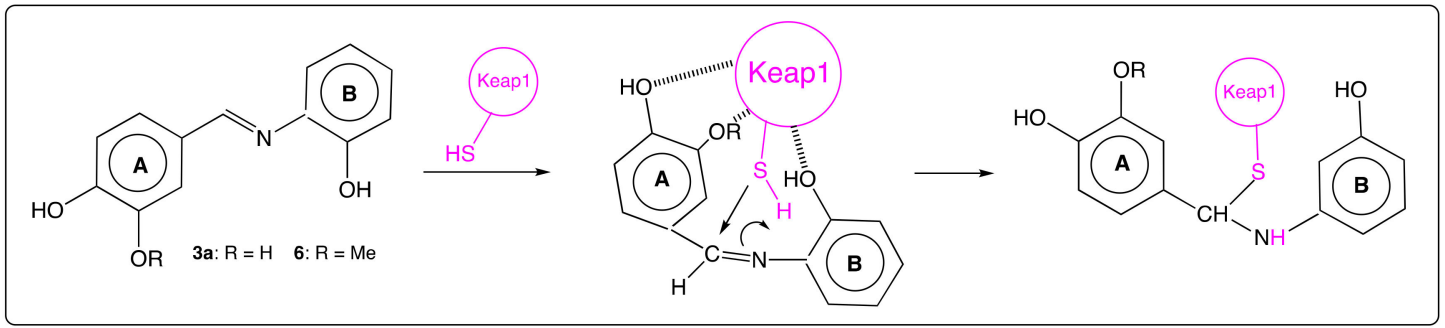

Figure 8. Suggested mechanism in the adduct of Keap1 protein on AZA-ST 3a and 6. (Inspired from [33]).

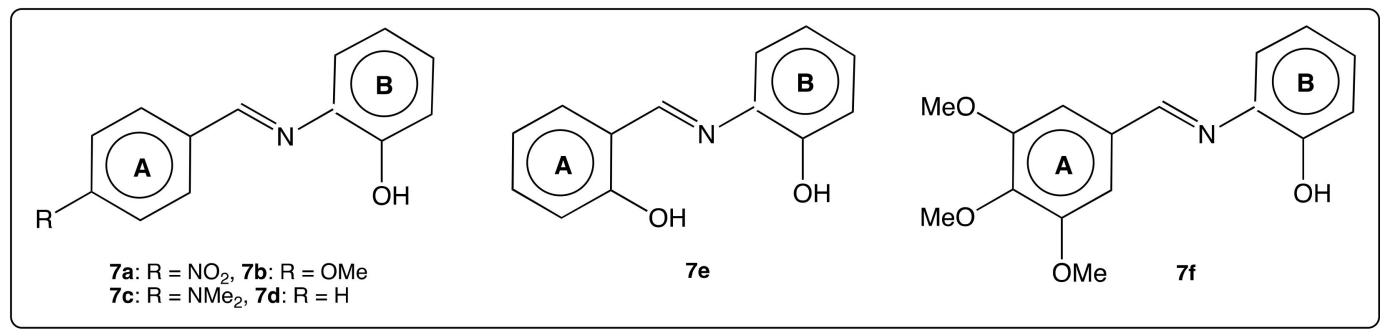

Figure 9. Structure of AZA-ST 7a-f [62].

\subsection{Aza-Stilbenes Bearing A Catechol Group on Cycle A}

Murias's group has reported several studies on polyhydroxylated stilbenes bearing catechol or pyragollol groups on one or both aromatic cycles. They have highlighted the crucial roles of such groups in anti-oxidant activities and subsequently anti-tumoral activities of such polyhydroxylated stilbenes compared to that of RSV, which bears a resorcinol group (Figure 10) [63]. Indeed, as it was demonstrated by Wright [52], a phenoxyl radical formed from a catechol group may rise to a stabilized ortho-quinone, that it is not achievable with a resorcinol group. Thus, polyhydroxylated stilbenes bearing a catechol or a pyrogallol group provide better antioxidant and antitumoral activities than RSV.

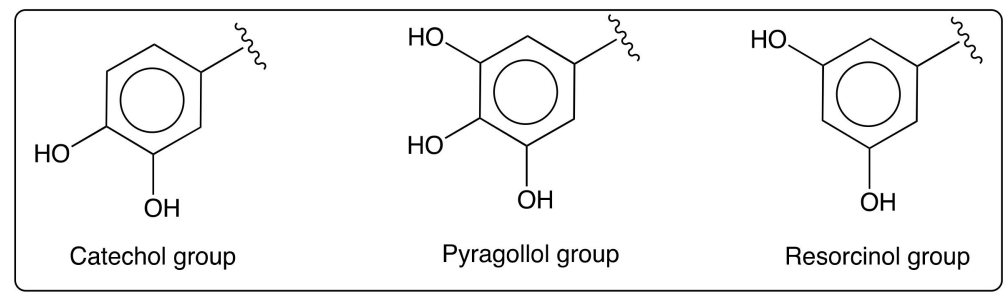

Figure 10. Catechol, pyrogallol and resorcinol groups [55].

In the case of catecholic aza-stilbenes, we have mentioned the above example of aza-stilbene 3a (Figure 5) providing efficient anti-oxidant activities [51]. However, this feature was attributed to both the catechol group on cycle A and the phenol group in ortho position of cycle B. In the following examples, it will be shown that only catechol group on cycle A may be responsible for biological activities. Catechol compounds AZA-ST 8a-b and phenol compounds AZA-ST 9a-e (Figure 11) were synthesized and evaluated for their ability to scavenge GO radical [64]. The authors have shown that GO radical scavenging reaction rates of $\mathbf{8} \mathbf{a}-\mathbf{b}$ were higher than those of RSV and $\mathbf{9 a}-\mathbf{e}$. Lu's group also reported a weak DPPH radical scavenging activity for AZA-ST $\mathbf{9 a - e}$ [51]. In addition, $\mathbf{8} \mathbf{a}-\mathbf{b}$ provided better antiproliferative activity against human hepatoma HepG2 cells than RSV and $\mathbf{9 a}-\mathbf{e}$ with $\mathrm{IC}_{50}$ values 14 -fold and 11.7-fold lower than RSV IC 50 values, respectively. Regarding catecholic AZA-ST $\mathbf{8} \mathbf{a}-\mathbf{b}$, the results highlight a correlation between anti-oxidant and anti-proliferative activities as well as the crucial role of the catechol group in anti-oxidant activities of such RSV analogs.

Bhat's group has reported the ability of AZA-ST 8a and 8c (Figure 11) to inhibit the growth of human breast cancer cell lines (MDA-MB-231, which is estrogen receptors (ER) negative and expresses 
mutated p53, and T47D, which is ER $\alpha$ positive) $[46,65,66]$. A docking study has allowed to show that (thanks to catechol groups) Van der Waals bonds might be promoted between the amino acid residues of protein in receptor ER $\alpha$ cavity and AZA-ST 8a and 8c. They would lead to a better stabilization of the imino RSV analogs into the protein pocket than RSV itself [46]. In subsequent studies, the same authors have highlighted that AZA-ST 8a and 8c might act on both estrogen receptors by inhibiting $\mathrm{ER} \alpha$ expression and promoting ER $\beta$ expression $[65,66]$.

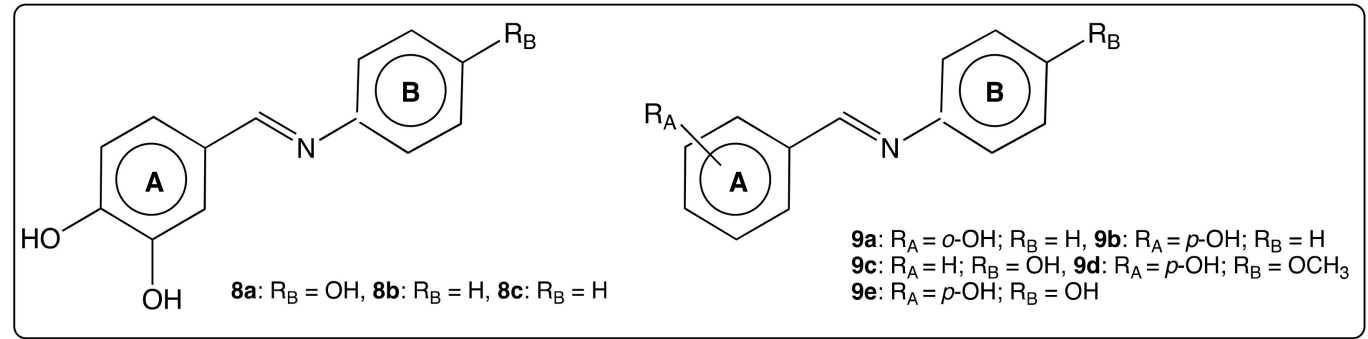

Figure 11. Structure of AZA-ST 8a-c and 9a-e [64].

\section{Biological Activities of Azo-Stilbenes AZO-ST}

Two series of azo-stilbenes AZO-ST 10 and AZO-ST 11 (Figure 12) were synthesized and evaluated in vitro for their antifungal activities against seven phytopathogenic fungi [67]. AZO-ST 11, bearing a hydroxyl group in the ortho position of aromatic cycle A were less efficient than hymexazol the commercially agricultural fungicide (Figure 12). In contrast, AZO-ST 10 was efficient towards such fungi; some of them were more efficient than hymexazol. The substitution by a hydroxyl group in the para position of the aromatic cycle A and additionally by a methyl group in the ortho position of cycle A, seemed to be crucial structural parameters for AZO-ST 10 to get promising antifungal properties.

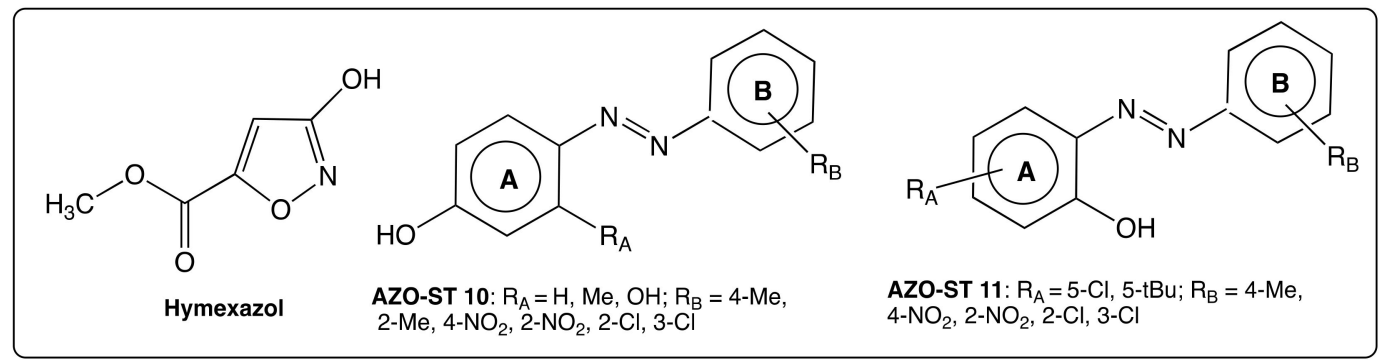

Figure 12. Structure of hymexazol and structure of compounds of the AZO-ST series $\mathbf{1 0}$ and AZO-ST series 11 [67].

Azo-stilbenes AZO-ST 12 (Figure 13) substituted with hydroxyl or methoxyl groups were synthesized and tested in vitro as potent tyrosinase inhibitors [49]. Azo-resveratrol (12a) and azo-pterostilbene (12b) with the para hydroxy group on cycle A had the best inhibition activities against mushroom tyrosinase in this series similar to those of RSV itself. In Figure 13, it is highlighted that the slightest modification of a group and of its position on both aromatic rings may have a great impact on the ability to inhibit tyrosinase. It can also be observed that even the induction of the para hydroxyl group is central, the role of the ortho hydroxyl group on cycle A is moderate and may be easily disturbed by a methoxyl group lying nearby.

The same research group has refined the structure of the compounds of the AZO-ST series 12 taking into account both important effects of the para hydroxyl group and the moderate effect of the ortho hydroxyl group in cycle A in the inhibitory activity on mushroom tyrosinase [32]. Four new compounds in the AZA-ST series 13a-d (Figure 14) were synthesized, evaluated in vitro as potent mushroom tyrosinase inhibitors and compared with kojic acid (Figure 6) and RSV. Overall, compounds 13a- $\mathbf{d}$ are more active than both reference compounds and $\mathrm{IC}_{50}$ values are $17.85,49.08$ and $59.80 \mu \mathrm{M}$ 
for 13b, kojic acid and RSV, respectively. Tyrosinase exists widely in bacteria, fungi, plants, insects, vertebrates and invertebrates and is the rate limiting enzyme in the biosynthesis of melanin pigments responsible for colors in hair, skin and eyes. In such series, there are no more methoxyl groups whereas the number of hydroxyl group drops while two compounds bear a tosyl-oxy group. Thus, molecular structures being more stripped towards those of AZA-ST 12, it is easier to see the influence of para and/or ortho hydroxyl groups. The weak percentage of tyrosinase inhibition obtained with 13a shows that the combination of para and ortho hydroxyl groups is required to get potent tyrosinase inhibitors and subsequently, promising therapeutic agents to treat skin diseases (hyperpigmentation, lentigo, vitiligo and skin cancers) [68].

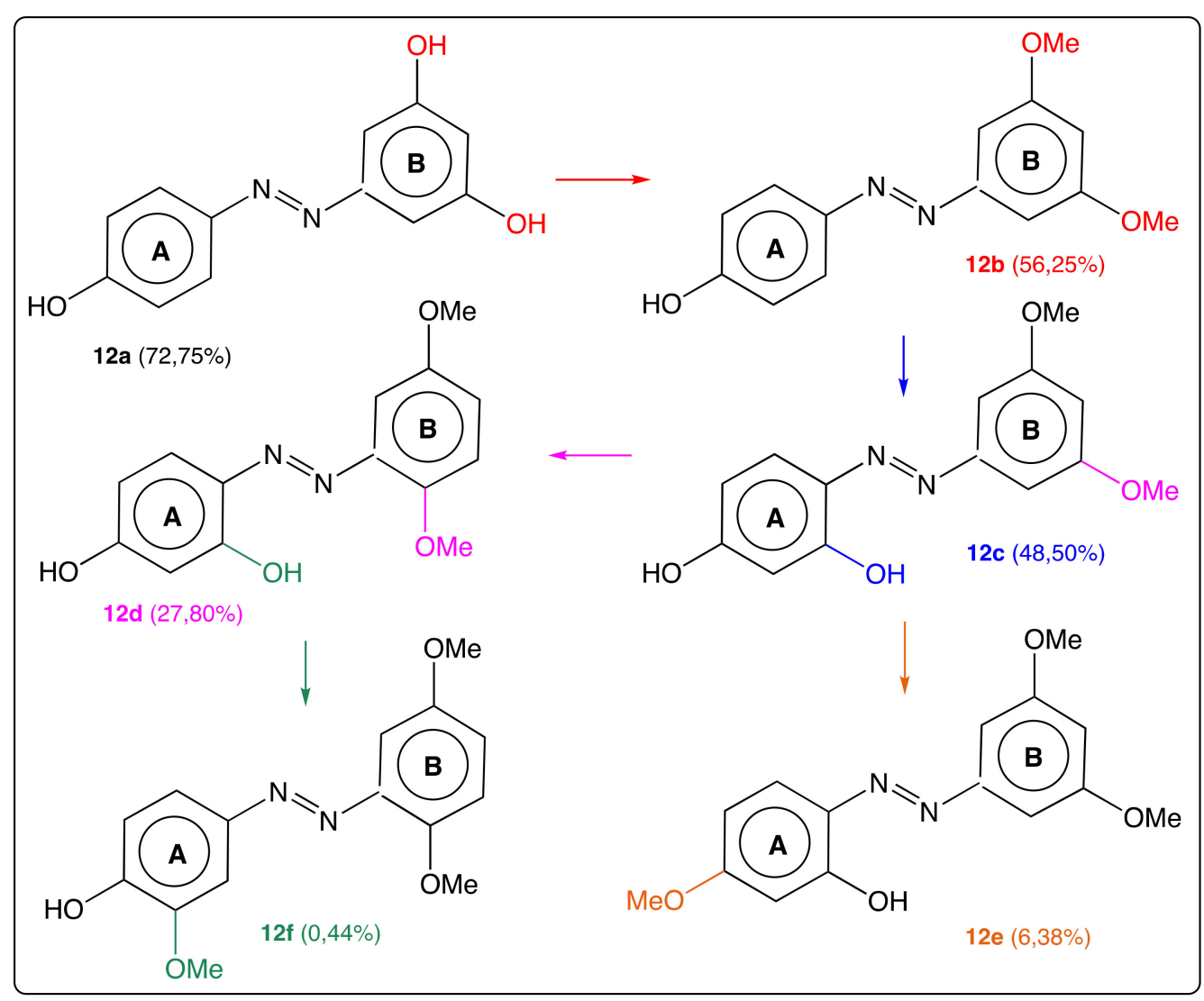

Figure 13. Structure of AZO-ST 12a-f (and percentage of tyrosinase inhibition) [49].

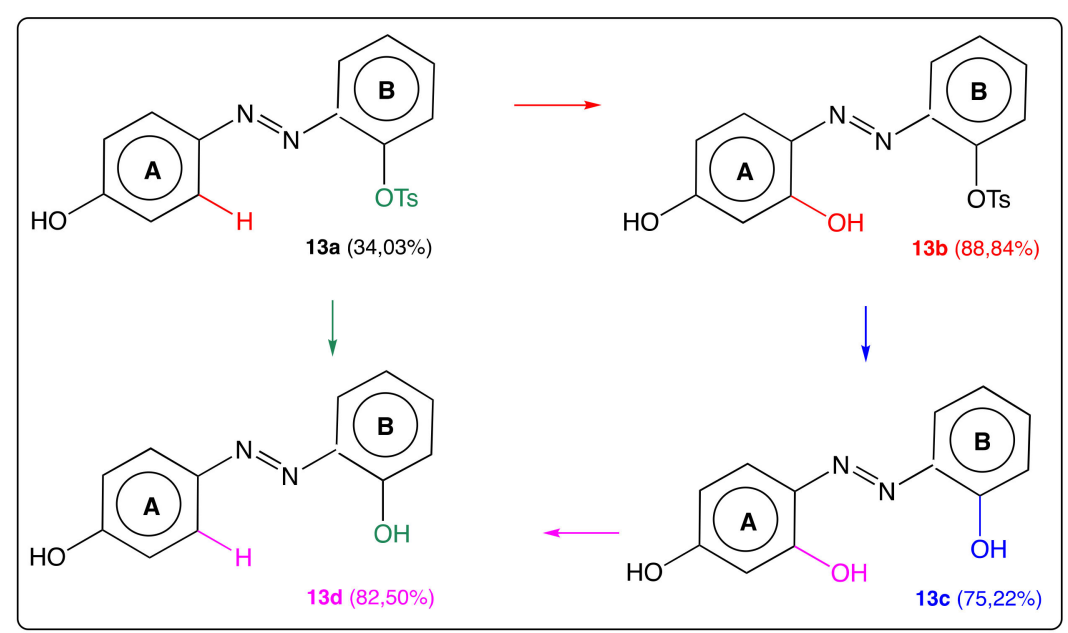

Figure 14. Structure of AZO-ST 13a-d (and percentage of tyrosinase inhibition) [32]. 


\section{Conclusions}

AZA-ST and AZO-ST are isosteric RSV derivatives in which the lone electronic pair(s) of nitrogen atom(s) bring different electronic effects in the molecular structure compared to that of RSV. In the case of aza-stilbenes, the dissymmetric imino linkage induces a polarization of this bond and subsequent nucleophilic attacks [33]. The replacement of one or both carbon atoms of the double bond between the mono- or poly-hydroxylated aromatic rings provides attractive biological properties to AZA-ST and AZO-ST such as antioxidant activities [51,64]. Some of them may be promising candidates to treat diseases whose current treatments are either non-existent or weakly efficient especially breast cancer with ER $\alpha$ negative [46,65,66], leishmaniasis and tuberculosis [62] and skin diseases [68]. Finally, the compounds of AZO-ST series $\mathbf{1 0}$ and $\mathbf{1 1}$ also show greater anti-fungal activities than hymexazol, a commercially available agricultural fungicide [67]. Some diazo compounds are photoactivatable and may interact with proteins and nucleic acids. Hence, such features should be taken into account to avoid interferences with biochemical tests used to define their biological activities [69]. Given the easy syntheses and biological potential of AZA-ST and AZO-ST, the development of such isosteric RSV derivatives may be a perspective of interest to highlight promising therapeutic and fungicide agents.

Author Contributions: D.V.-F., G.L. and N.L. conceptualized this review; the state of the art and bibliographic work were conducted by D.V.-F.; writing-review and editing, D.V.-F., G.L. and N.L.; supervision, D.V.-F. All authors have read and agreed to the published version of the manuscript.

Funding: This work was jointly supported by the COST Action CA16112 NutRedOx, the CNRS, the Université de Bourgogne (CoMUE BFC), the Conseil Régional through the "Plan d'Action Régionale pour l'Innovation" (PARI) and the European Union through the PO FEDER-FSE Bourgogne 2014/2020.

Acknowledgments: Richard Decréau is acknowledged for English corrections.

Conflicts of Interest: The authors declare no conflict of interest.

\section{References}

1. Takaoka, M. Phenolic substances of white hellebore (Veratrum grandiflorum Loes. fil.). J. Faculty Sci. 1940, 3 , 1-16. [CrossRef]

2. Arichi, H.; Kimura, Y.; Okuda, H.; Baba, M.; Kozowa, K.; Arichi, S. Effects of stilbene compounds of the roots of Polygonum cuspidatum Sieb. et Zucc. on lipid metabolism. Chem. Pharm. Bull. 1982, 30, 1766-1770. [CrossRef] [PubMed]

3. Burns, J.; Yokota, T.; Ashihara, H.; Lean, M.E.J.; Crozier, A. Plant foods and herbal sources of resveratrol. J. Agric. Food Chem. 2002, 50, 3337-3340. [CrossRef] [PubMed]

4. Adrian, M.; Jeandet, P. Effects of resveratrol on the ultrastructure of Botrytis cinerea conidia and biological significance in plant/pathogen interactions. Fitoterapia 2012, 83, 1345-1350. [CrossRef]

5. Pawlus, A.D.; Sahli, R.; Bisson, J.; Rivière, C.; Delaunay, J.C.; Richard, T.; Gomes, E.; Bordenave, L.; Waffo-Teguo, P.; Mérillon, J.M. Stilbenoid profiless of canes from Vitis and Muscadinia species. J. Agric. Food Chem. 2013, 61, 501-511. [CrossRef]

6. Boutegrabet, L.; Fekete, A.; Hertkorn, N.; Papastamoulis, Y.; Waffo-Téguo, P.; Mérillon, J.M.; Jeandet, P.; Gougeon, R.D.; Schmitt-Koplin, P. Determination of stilbene derivatives in Burgundy red wines by ultra-high pressure liquid chromatography. Anal. Bioanal. Chem. 2011, 401, 1517-1525. [CrossRef]

7. Gülçin, I. Antioxidant properties of resveratrol: A structure-activity insight. Innov. Food Sci. Emerg. Technol. 2010, 11, 210-218. [CrossRef]

8. Khan, O.S.; Bhat, A.A.; Krishnankutty, R.; Mohammad, R.M.; Uddin, S. Therapeutic potential of resveratrol in lymphoid malignancies. Nutr. Cancer 2016, 68, 365-373. [CrossRef]

9. Yiu, C.Y.; Chen, S.Y.; Chang, L.K.; Chiu, Y.F.; Lin, T.P. Inhibitory effects of resveratrol on the Epstein-Barr virus lytic cycle. Molecules 2010, 15, 7115-7124. [CrossRef]

10. Tili, E.; Michaille, J.J.; Adair, B.; Alder, H.; Limagne, E.; Taccioli, C.; Ferracin, M.; Delmas, D.; Latruffe, N.; Croce, C.M. Resveratrol decreases the levels of miR-155 by upregulating miR-663, a microRNA targeting JunB and JunD. Carcinogenesis 2010, 31, 1561-1566. [CrossRef] 
11. Kaminski, J.; Lançon, A.; Aires, V.; Limagne, E.; Tili, E.; Michaille, J.J.; Latruffe, N. Resveratrol initiates differentiation of mouse skeletal muscle-derived C2C12 myoblasts. Biochem. Pharmacol. 2012, 84, 1251-1259. [CrossRef] [PubMed]

12. Namsi, A.; Nury, T.; Hamdouni, H.; Yammine, A.; Vejux, A.; Vervandier-Fasseur, D.; Latruffe, N.; Masmoudi-Kouki, O.; Lizard, G. Induction of neuronal differentiation of murine N2a cells by two polyphenols present in the mediterranean diet mimicking neurotrophins activities: Resveratrol and apigenin. Diseases 2018, 6, 67. [CrossRef] [PubMed]

13. Singh, N.; Agrawal, M.; Doré, S. Neuroprotective properties and mechanisms of resveratrol in in vitro and in vivo experimental cerebral stroke models. ACS Chem. Neurosci. 2013, 4, 1151-1162. [CrossRef] [PubMed]

14. Stef, G.; Csiszar, A.; Lerea, K.; Ungvari, Z.; Veress, G. Resveratrol inhibits aggregation of platelets from high-risk cardiac patients with aspirin resistance. J. Cardiovasc. Pharmacol. 2006, 48, 1-5. [CrossRef]

15. Wood, J.G.; Rogina, B.; Lavu, S.; Howitz, K.; Helfand, S.L.; Tatar, M.; Sinclair, D. Sirtuin activators mimic caloric restriction and delay ageing in metazoans. Nature 2004, 430, 686-689. [CrossRef]

16. Markus, M.A.; Morris, B.J. Resveratrol in prevention and treatment of common clinical conditions of aging. Clin. Interv. Aging 2008, 3, 331-339.

17. Westphal, C.H.; Dipp, M.A.; Guarente, L. A therapeutic role for situins in diseases of aging? Trends Biochem. Res. 2007, 32, 555-560. [CrossRef]

18. Bonkowski, M.S.; Sinclair, D.A. Slowing ageing by design: The rise of $\mathrm{NAD}^{+}$and sirtuin-activating compounds. Nat. Rev. Mol. Cell Biol. 2016, 17, 679-690. [CrossRef]

19. Salvatore Benito, A.; Valero Zanuy, M.Á.; Alarza Cano, M.; Ruiz Alonso, A.; Alda Bravo, I.; Rogero Blanco, E.; Maíz Jiménez, M.; León Sanz, M. Adherence to Mediterranean diet: A comparison of patients with head and neck cancer and healthy population. Endocrinol. Diabetes Nutr. 2019, 66, 417-424. [CrossRef]

20. Sun, X.; Peng, B.; Yan, W. Measurement and correlation of solubility of trans-resveratrol in 11 solvents at $\mathrm{T}=$ (278.2, 282.2, 298.2, 308.2 and 318.2) K. J. Chem. Thermodyn. 2008, 40, 735-738. [CrossRef]

21. Delmas, D.; Aires, V.; Limagne, E.; Dutartre, P.; Mazué, F.; Ghiringhelli, F.; Latruffe, N. Transport, stability and biological activity of resveratrol. Ann. N. Y. Acad. Sci. 2011, 1215, 48-59. [CrossRef] [PubMed]

22. Cardile, V.; Chillemi, R.; Lombardo, L.; Sciuto, S.; Spatafora, C.; Tringali, C. Antiproliferative activity of methylated analogues of E- and Z-resveratrol. Z. Naturforsch. C 2007, 62, 189-195. [CrossRef] [PubMed]

23. Liu, Q.; Kim, C.T.; Jo, Y.H.; Kim, S.B.; Hwang, B.Y.; Lee, M.K. Synthesis and biological evaluation of resveratrol derivatives as melanogenesis inhibitors. Molecules 2015, 20, 16933-16945. [CrossRef] [PubMed]

24. Nawaz, W.; Zhou, Z.; Deng, S.; Ma, X.; Ma, X.; Li, C.; Shu, X. Therapeutic versatility of resveratrol derivatives. Nutrients 2017, 9, 1188. [CrossRef] [PubMed]

25. Chalal, M.; Vervandier-Fasseur, D.; Meunier, P.; Cattey, H.; Hierso, J.C. Syntheses of polyfunctionalized resveratrol derivatives using Wittig and Heck protocols. Tetrahedron 2012, 68, 3899-3907. [CrossRef]

26. Chalal, M.; Klinguer, A.; Echairi, A.; Meunier, P.; Vervandier-Fasseur, D.; Adrian, M. Antimicrobial activity of resveratrol analogues. Molecules 2014, 19, 7679-7688. [CrossRef]

27. Chalal, M.; Delmas, D.; Meunier, P.; Latruffe, N.; Vervandier-Fasseur, D. Inhibition of cancer derived cell lines proliferation by newly synthesized hydroxylated stilbenes and ferrocenyl-stilbene analogs. Comparison with resveratrol. Molecules 2014, 19, 7850-7868. [CrossRef]

28. Latruffe, N.; Vervandier-Fasseur, D. Strategic syntheses of vine and wine resveratrol derivatives to explore their effects on cell functions and dysfunctions. Diseases 2018, 6, 110. [CrossRef]

29. Belluti, F.; Fontana, G.; Dal Bo, L.; Carenini, N.; Giommarelli, C.; Zunino, F. Design, synthesis and anticancer activities of stilbene-coumarin hybrid compounds: Identification of novel proapopoptic agents. Bioorg. Med. Chem. 2010, 18, 3543-3550. [CrossRef]

30. Conti, C.; Desideri, N. New 4H-chromene-4-one and 2H-chromene derivatives as anti-picornavirus capsid-binders. Bioorg. Med. Chem. 2010, 18, 6480-6488. [CrossRef]

31. Lima, L.M.; Barreiro, E.J. Bio-isosterism: A useful strategy for molecular modification and drug design. Curr. Med. Chem. 2005, 12, 23-49. [CrossRef] [PubMed]

32. Bae, S.J.; Ha, Y.M.; Kim, J.A.; Park, J.Y.; Ha, T.K.; Park, D.; Chun, P.; Park, N.H.; Moon, H.R.; Chung, H.Y. A novel synthesized tyrosinase inhibitor: (E)-2-((2,4-dihydrophenyl)diazinyl)phenyl-4-methylbenzenesulfonate as an azo-resveratrol analog. Biosci. Biotechnol. Biochem. 2013, 77, 65-72. [CrossRef] [PubMed]

33. Li, C.; Xu, X.; Wang, X.J.; Pan, Y. Imine resveratrol analogues: Molecular design, Nrf2 activation and SAR analysis. PLoS ONE 2014, 9, e101455. [CrossRef] [PubMed] 
34. Mayhoub, A.S.; Marler, L.; Kondratyuk, T.P.; Park, E.J.; Pezzuto, J.M.; Cushman, M. Optimization of the aromatase inhibitory activities of pyridylthiazole analogues of resveratrol. Bioorg. Med. Chem. 2012, 20, 2427-2434. [CrossRef] [PubMed]

35. Bellina, F.; Guazzelli, N.; Lessi, M.; Manzini, C. Imidazole analogues of resveratrol: Synthesis and cancer cell growth evaluation. Tetrahedron 2015, 71, 2298-2305. [CrossRef]

36. Santos, A.C.; Pereira, I.; Pereira-Silva, M.; Ferreira, L.; Caldas, M.; Magalhaes, M.; Figueiras, A.; Ribeiro, A.J.; Veiga, F. Nanocariers for resveratrol delivery: Impact on stability and solubility concerns. Trends Food Sci. Technol. 2019, 91, 483-497. [CrossRef]

37. Moshawih, S.; Mydin, R.B.S.M.N.; Kalakotla, S.; Jarrar, Q.B. Potential applications of resveratrol in nanocarriers against cancer: Overview and future trends. J. Drug Deliv. Sci. Technol. 2019, 53, 101187. [CrossRef]

38. Intagliata, S.; Modica, M.N.; Santagati, L.M.; Montenegro, L. Strategies to improve resveratrol systemic and topical bioavailability: An update. Antioxidants 2019, 8, 244. [CrossRef]

39. Lian, B.; Wu, M.; Feng, Z.; Deng, Y.; Zhong, C.; Zhao, X. Folate-conjugated human serum albuminencapsulated resveratrol nanoparticles: Preparation, characterization, bioavailability and targeting of liver tumors. Artif. Cells Nanomed. Biotechnol. 2019, 47, 154-165. [CrossRef]

40. Xiao, Y.; Chen, H.; Song, C.; Zeng, X.; Zheng, Q.; Zhang, Y.; Lei, X.; Zheng, X. Pharmacological activities and structure-modification of resveratrol analogues. Pharmazie 2015, 70, 765-771.

41. Biasutto, L.; Mattarei, A.; Azzolini, M.; La Spina, M.; Sassi, N.; Romio, M.; Paradisi, C.; Zoratti, M. Resveratrol derivatives as a pharmacological tool. Ann. N. Y. Acad. Sci. 2017, 1403, 27-37. [CrossRef] [PubMed]

42. Giacomini, E.; Rupiani, S.; Guidotti, L.; Recanatini, M.; Roberti, M. The use of stilbene scaffold in medicinal chemistry and Multi Target Drug design. Curr. Med. Chem. 2016, 23, 2439-2489. [CrossRef] [PubMed]

43. Solladié, G.; Pasturel-Jacopé, Y.; Maignan, J. A re-investigation of resveratrol synthesis by Perkin reaction. Application to the synthesis of aryl cinnamic acids. Tetrahedron 2003, 59, 3315-3321. [CrossRef]

44. Das, J.; Pany, S.; Majhi, A. Chemical modifications of resveratrol for improved protein kinase C alpha activity. Bioorg. Med. Chem. 2011, 19, 5321-5333. [CrossRef]

45. Tudose, A.; Maj, A.; Sauvage, X.; Delaude, L.; Demonceau, A.; Noels, A.F. Synthesis of stilbenoids via the Suzuki-Miyaura reaction catalyzed by palladium $\mathrm{N}$-heterocyclic carbene complexes. J. Mol. Cat. A Chem. 2006, 257, 158-166. [CrossRef]

46. Siddiqui, A.; Dandawate, P.; Rub, R.; Padhye, S.; Aphale, S.; Moghe, A.; Jagyasi, A.; Swamy, K.V.; Singh, B.; Chatterjee, A.; et al. Novel aza-resveratrol analogs: Synthesis, characterization and anti-cancer activity against breast cancer cell lines. Bioorg. Med. Chem. Lett. 2013, 23, 635-640. [CrossRef]

47. Kim, S.; Ko, H.; Park, J.E.; Jung, S.; Lee, S.K.; Chun, Y.J. Design, synthesis and discovery of novel trans-stilbene analogues as potent and selective human cytochrome P450 1B1 inhibitors. J. Med. Chem. 2002, 45, 160-164. [CrossRef]

48. Kotora, P.; Sersen, F.; Filo, J.; Loos, D.; Gregan, J.; Gregan, F. The scavenging of DPPH, galvinoxyl and ABTS radicals by imine analogs of resveratrol. Molecules 2016, 21, 127. [CrossRef]

49. Song, Y.M.; Ha, Y.M.; Kim, J.A.; Chung, K.W.; Uehara, Y.; Lee, K.J.; Chun, P.; Byun, Y.; Chung, H.Y.; Moon, H.R. Synthesis of novel azo-resveratrol, azo-oxyresveratrol and their derivatives as potent tyrosinase inhibitors. Bioorg. Med. Chem. Lett. 2012, 22, 7451-7455. [CrossRef]

50. Tang, Y.Z.; Liu, Z.Q. Free-radical scavenging effect of carbazole derivatives on DPPH and ABTS radicals. Cell Biochem. Funct. 2007, 2, 149-158. [CrossRef]

51. Lu, J.; Li, C.; Chai, Y.F.; Yang, D.Y.; Sun, C.R. The anti-oxidant effect of imine resveratrol analogues. Bioorg. Med. Chem. Lett. 2012, 22, 5744-5747. [CrossRef] [PubMed]

52. Wright, J.S.; Johnson, E.J.; DiLabio, G.A. Predicting the activity of phenolic antioxidants: Theoretical method, analysis of substituents effects, and application to major families of antioxidants. J. Am. Chem. Soc. 2001, 123, 1173-1183. [CrossRef] [PubMed]

53. Zhang, Y.; Zou, B.; Pan, Y.; Liang, H.; Yi, X.; Wang, H. Antioxidant activities and transition metal ion chelating studies of some hydroxyl Schiff base derivatives. Med. Chem. Res. 2012, 21, 1341-1346. [CrossRef]

54. Anekonda, T.S. Resveratrol-A boon for treating Alzheimer's disease? Brain Res. Rev. 2006, 52, $316-326$. [CrossRef] [PubMed]

55. Jang, J.H.; Surh, Y.J. Protective effect of resveratrol on $\beta$-amyloid-induced oxidative PC12 cell death. Free Rad. Biol. Med. 2003, 34, 1100-1110. [CrossRef] 
56. Mancino, A.M.; Hindo, S.S.; Kochi, A.; Lim, M.H. Effects of clioquinol on metal-triggered amyloid- $\beta$ aggregation revisited. Inorg. Chem. 2009, 48, 9596-9598. [CrossRef]

57. Martinez, A.; Alcendor, R.; Rahman, T.; Podgorny, M.; Sanogo, I.; McCurdy, R. Ionophoric polyphenols selectively bind $\mathrm{Cu}^{2+}$, display potent antioxidant and anti-amyloidogenic properties, and are non-toxic toward Tetrahymena thermophila. Bioorg. Med. Chem. 2016, 24, 3657-3670. [CrossRef]

58. Yang, X.; Qiang, X.; Li, Y.; Luo, L.; Xu, R.; Zheng, Y.; Cao, Z.; Tan, Z.; Deng, Y. Pyridoxine-resveratrol hybrids Mannich base derivatives as novel dual inhibitors of AChE and MAO-B with anti-oxidant and metal-chelating properties for the treatment of Alzheimer's disease. Bioorg. Chem. 2017, 71, 305-314.

59. Battaini, G.; Monzani, E.; Casella, L.; Santagostini, L.; Pagliarin, R. Inhibition of the catecholase activity of biomimetic dinuclear copper complexes by kojic acid. J. Biol. Inorg. Chem. 2000, 5, 262-268. [CrossRef]

60. Lima, L.L.; Lima, R.M.; da Silva, A.F.; do Carmo, A.M.R.; da Silva, A.D.; Raposo, N.R.B. Azastilbene analogs as tyrosinase inhibitors: New molecules with depigmenting potential. ScientificWorldJournal 2013, 2013, 274643. [CrossRef]

61. Zimmermann-Franco, D.C.; Esteves, B.; Lacerda, L.M.; de Oliveira Souza, I.; dos Santos, J.A.; de Castro Campos Pinto, N.; Scio, E.; da Silva, A.D.; Macedo, G.C. In vitro and in vivo anti-inflammatory properties of imine resveratrol analogues. Bioorg. Med. Chem. 2018, 26, 4898-4906. [CrossRef] [PubMed]

62. Coimbra, E.S.; Santos, J.A.; Lima, L.L.; Machado, P.A.; Campos, D.L.; Pavan, F.R.; Silva, A.D. Synthesis, antitubercular and leishmanicidal evaluation of resveratrol analogues. J. Braz. Chem. Soc. 2016, 27, 2161-2166. [CrossRef]

63. Kucinska, M.; Piotrowska, H.; Luczak, M.W.; Mikula-Pietrasik, J.; Ksiazek, K.; Wozniak, M.; Wierzchowski, M.; Dudka, J.; Jäger, W.; Murias, M. Effects of hydroxylated resveratrol analogs on oxidative stress and cancer cells death in human acute $\mathrm{T}$ cell leukemia cell line: Prooxidative potential of hydroxylated resveratrol analogs. Chem. Biol. Interact. 2014, 209, 96-110. [CrossRef] [PubMed]

64. Cheng, L.X.; Tang, J.J.; Luo, H.; Jin, X.L.; Dai, F.; Yang, J.; Qian, Y.P.; Li, X.Z.; Zhou, B. Antioxidant and antiproliferative activities of hydroxyl-substituted Schiff bases. Bioorg. Med. Chem. Lett. 2010, 20, 2417-2420. [CrossRef]

65. Ronghe, A.; Chatterjee, A.; Singh, B.; Dandawate, P.; Murphy, L.; Bhat, N.K.; Padhye, S.; Bhat, H.K. Differential regulation of estrogen receptors $\alpha$ and $\beta$ by 4-(E)-\{(4-hydroxyphenylimino)-methylbenzene-1,2-diol $\}$, a novel resveratrol analog. J. Steroid Biochem. Mol. Biol. 2014, 144, 500-512. [CrossRef]

66. Ronghe, A.; Chatterjee, A.; Singh, B.; Dandawate, P.; Abdalla, F.; Bhat, N.K.; Padhye, S.; Bhat, H.K. 4-(E)-\{(p-tolylimino)-methylbenzene-1,2-diol\}, a novel resveratrol differentially regulates estrogen receptors $\alpha$ and $\beta$ in breast cancer cells. Toxicol. Appl. Pharmacol. 2016, 301,1-13. [CrossRef]

67. Xu, H.; Zeng, X. Synthesis of diaryl-azo derivatives as potential antifungal agents. Bioorg. Med. Chem. Lett. 2010, 20, 4193-4195. [CrossRef]

68. Deri, B.; Kanteev, M.; Goldfeder, M.; Lecina, D.; Guallar, V.; Adir, N.; Fishman, A. The unravelling of the complex pattern of tyrosinase inhibition. Sci. Rep. 2016, 6, 34993. [CrossRef]

69. Algarni, A.S.; Hargreaves, A.J.; Dickenson, J.M. Activation of transglutaminase 2 by nerve growth factor in differentiating neuroblastoma cells: A role in cell survival and neurite outgrowth. Eur. J. Pharmacol. 2018, 820, 113-129. [CrossRef]

(C) 2020 by the authors. Licensee MDPI, Basel, Switzerland. This article is an open access article distributed under the terms and conditions of the Creative Commons Attribution (CC BY) license (http://creativecommons.org/licenses/by/4.0/). 